\title{
Premarital sexual practice and associated factors among robe TVET students at robe town, bale zone, Oromia region, southeast Ethiopia, 2016
}

\begin{abstract}
Background: Premarital sexual practice among unmarried preparatory, College \& university level students have markedly increased recently in Ethiopia. Those students found in adolescent are recognized as most affected by sexually transmitted infections including HIV/AIDS. Sexual activity among unmarried people who do not have access to information about reproductive health and birth control can also increase the rate of unwanted early pregnancy too. A cross sectional study among TVET students was conducted from April-May 2016.Three hundred eighty seven adolescent students were participated. A self-administered questionnaire was provided. The data were cleaned, entered, processed and analyzed using SPSS V.21. The results was summarized in frequencies and percentages and presented in tables, pie chart and graph. The prevalence of premarital sexual practice among the TVET students was $51.9 \%$. Being Male, family monthly income, alcohol consumption, cigarette smoking and chewing chat were factors associated with premarital sexual practice. Premarital sexual practice was more likely to occur among male adolescent students, $[\mathrm{AOR}=2.638,95 \% \mathrm{Cl}$ $(1.731,3.950)]$, alcohol consumption $[\mathrm{AOR}=3.566,95 \% \mathrm{CI}(2.650,4.773)$, chewing chat, $[\mathrm{AOR}=2.606,95 \% \mathrm{CI}(1.526,4.451)]$ and cigarette smoking, $[\mathrm{AOR}=6.451$, $95 \%$ CI $(3.332,12.501)]$. But it was found to be less likely among students whom their family's monthly income is $>4500 \mathrm{ETB}$, [A0R $=0.268,95 \% \mathrm{CI}(0.137,0.524)]$ and $3501-4500$ ETB, [AOR $0.274,95 \%(0.143,0.525)]$. Hence, this study showed that the prevalence of premarital sex practice among the study participants is higher $(52 \%)$. Awareness creation should be done among TVET students to avoid unhealthy behaviors like substance use (drinking alcohol), watching videos that push them to start pre-marital sexual practice.
\end{abstract}

Keywords: adolescent, HIV/aids, TVET students, alcohol consumption, reproductive health, dating, inadequate education, sexual behavior, population, activities
Volume 5 Issue 6 - 2017

\author{
Abdurehman Kalu Tololu, Semere Sileshi \\ Belda, Belew Abiye Worku, Girma Nigatu \\ Deressa, Roda Nasir Hassan, Teshale Merga \\ Gudeta
}

Madda Walabu University, Ethiopia

Correspondence: Abdurehman Kalu Tololu, Madda Walabu University, Ethiopia, Tel +25I 924545690 , Email abdurehmankelu900@gmail.com

Received: April 05, 2017| Published: May 08, 2017
Abbreviations: AIDS, acquired immune deficiency syndrome; BSS, behavioral surveillance survey; $\mathrm{CBE}$, community based education; CD, compact disc; ETB, Ethiopian birr; HIV, human immunodeficiency virus; MOF, ministry of health; $\mathrm{RH}$, reproductive health; SPSS, statistical package for social science; STIs, sexually transmitted infections; TVET, technical vocational educational training; USA, united state America; $\mathrm{WHO}$, world health organization

\section{Introduction}

\section{Background}

World health organization (WHO) defines adolescent people as those between ages of 10-19years old. ${ }^{1}$ Young people undergo a period of development when biological, physical, cognitive, and social traits mature from childhood to adulthood. During this stage, the challenges that youth face and the decisions they make can have a tremendous impact on the quality and length of their lives. Many important life events and health-damaging behaviors that are contributing for pre-marital sexual activities start during theseyears. ${ }^{2}$ According to Ethiopian demographic and health survey (EDHS), 2011, 1.5\% of Ethiopian adults age 15-49 are infected with HIV and the number of women age 15-19years who tested positive for HIV is much higher than the number of males in the same age group which is due to early sexual initiation among young females and having multiple sexual partner. ${ }^{3}$ Premarital sex is penetrative vaginal or sexual intercourse performed between couples before marriage. Some people who advocate virginity and abstinence argue that those people engaged in such sexual practice may have sex with many sexual partners and may have high number of life time sexual partners. As a result, they may be liable to acquire STIs including HIV. Beside, females, particularly adolescent girls may end up with unwanted pregnancy, abortion, teenage deliveries and various complications of these including death. Moreover, the girls may drop out from school to rare their children and in most cases they become economically dependent upon their parents. ${ }^{4}$ The trend in sexual activity of adolescents at younger age increase in the world. In many countries the majority of young people are sexually active before age of 20 , premarital sex is common among 15-19years old. ${ }^{5}$ Family consent has been shown to have consistent and strong effects on the timing of sexual debut. Adolescent living in single-parent families or with stepparents initiates sexual activity. Dating, and especially early steady dating, provides a context for many adolescent sexual experience. Previous studies have shown that adolescents' attitudes about sex affect adolescent sexual behavior, more permissive attitudes lead to earlier first sex. ${ }^{6}$

\section{Statement of the problem}

One in every five people in the world is an adolescent, defined by World Health Organization as a person between 10 to 19years of 
age. Unsafe sex is a major threat to the health and survival of millions of adolescents. Each year, one in 20 adolescents worldwide contracts STI including HIV/AIDS. Every day, over 7000 young people aged from 10 to 24 years become infected with HIV/AIDS. Globally more than half of all new HIV infections are among 15 to 24years old. ${ }^{7,8}$ Early sexual initiation may predispose young people to HIV/AIDS as their chances of having several partners before marriage increases. ${ }^{9}$ Therefore, delaying the age of sexual debut and increased condom use is recommended in preventing HIV infection for this age group..$^{10}$ In many societies, premarital sex is a taboo, especially among unmarried girls. ${ }^{11}$ This norm is widespread in rural Ethiopia, as in many traditional societies too. ${ }^{12}$ A study about the concepts of HIV and AIDS in Ethiopia suggested that premarital sex may contribute to the expansion of HIV and AIDS. Indeed, several studies from Ethiopia have shown that young people are engaged in premarital sex with multiple sexual partners, and do not use condoms at all or use them irregularly. ${ }^{13}$ Adolescents in Ethiopia are also exposed to various risks such as unprotected sex, early marriage, early pregnancy, sexually transmitted infections (STIs) and HIV/AIDS, unemployment, drug abuse and crime. ${ }^{14}$ According to the study conducted in Ethiopia, $66.2 \%$ of the adolescents expressed that they had sexual intercourse and of those who had ever had sex, the age at first intercourse ranged from 8 to 31years with the mean age of 17.4 and females had their first intercourse at significantly younger age. In addition, out of the total respondents, $53.8 \%$ have regular partner while the remaining $46.2 \%$ reported no regular partners..$^{15}$ In order to tackle these problems, adolescents should learn to develop the life skill they need to survive in their environment. Life skill based education enables them to develop ability in critical thinking, problem solving, self-management and interpersonal Communication skills in order to adopt a healthy behavior. Because, when sexuality is discussed openly and when young people learn more about their bodies and their emotions, they are better able to cope with sexual maturation. ${ }^{16}$ Educational institutions like TVETs and Schools are the ideal places where adequate and accurate information be provided along with their formal education. Moreover, peer groups in school play a great role in information dissemination and help students internalize the facts that lead to behavioral change. Actually this needs an integrated effort of adolescents, school- teachers, the family and other relevant bodies. ${ }^{17}$ In general, many literatures suggest that the individual, family and peer variables have considerable influence on the sexual behavior of the youth. However, it is one of health related problem affecting large segment of youth in Ethiopia, due to the sensitivity of the topic of premarital sexuality; youth receive inadequate education, guidance and services on reproductive health. To fill the gap, it is thus imperative to study the prevalence of premarital sex and the factors surrounding premarital sex in the context of TVET students in order to inform Ministry of Health $(\mathrm{MOH})$, Ministry of Education and planners to develop appropriate and timely intervention programs to prevent high risk sexual behavior such as premarital sex and unsafe sexual practices in this segment of populations.

\section{Significance of the study}

The study revealed that the prevalence of premarital sex and unprotected sexual practice among TVET students is the critical issue to be studied. Because the students of these age groups are facing struggles on their activities because of immaturity, acquired new developmental stage and hotness. Hence, these students do not get adequate reproductive health services and may be practicing unsafe sex and exposed to HIV infection and other STIs. The result of this study is important to provide baseline information related to TVET students sexual behavior in the area and the baseline data will be used by different stakeholders like Ministry of Health, Ministry of Education and other Organizations to take appropriate measures to improve current sexual behavior of the students in order to prevent burdens following premarital sex and unprotected sexual activity such as sexually transmitted infections and unwanted pregnancy.

\section{Objective}

\section{General objective}

To assess the prevalence of premarital sexual practice and associated factors among students in Robe TVET College in Robe town, Bale Zone, South East Ethiopia, may 2016.

\section{Specific objectives}

a. To assess the magnitude of pre-marital sexual practice among students in Robe TVET College in Robe town.

b. To identify factors associated with premarital sexual practice among students in Robe TVET College, in Robe town.

\section{Methods and materials}

\section{Study area and period}

The study was conducted in Robe Town which is located in Bale Zone, one of the Oromia Zones and which is $430 \mathrm{~km}$ away from Addis Ababa, the capital city of Ethiopia. Robe town is surrounded by Sinja farmers association in South, Hawusho farmers association in South West, Horaboka farmers association in West, Sanbitu peasant association in North and Shallo farmers association in East. The total land coverage of the town is $80,240,000$ meter square. The estimated total population of the city in 2007 E.C was 68,987 of which 35,231 are male and the rest 33,756 are females (According to Robe municipality office). The town is found on 2500 meter above sea level with mean annual temperature of $12.5 \mathrm{C}$ and receive $12.5 \mathrm{~mm}$ amount of rain fall. The town has public health service like; Telecommunication, Postal service, five Elementary Schools, two High Schools, one Preparatory school, four private Colleges, two governmental Colleges and one public university. Robe TVET college is found in Bale Zone, in Robe town. The Robe TVET College is providing trainings for students who participate in developmental progression of the country by twenty one different types of department skills starting from Level I to IV. The number of students training in the college were 880 of which 434 male and 442 female students.

\section{Study design and period}

A cross-sectional study design from April to May, 2016.

\section{Population}

\section{Source population}

All students attending their regular education program at the time of data collection at Robe TVET College.

\section{Study population}

All sampled students at the time of data collection.

\section{Inclusion criteria}

All regular, unmarried students whose age greater than 15 years old. 


\section{Exclusion criteria}

Students who are critically ill or absent at the time of data collection were excluded from the study.

\section{Sample size determinations and sampling technique}

\section{Sample size determination}

The required sample size was calculated by using the following formula and p-value obtained from study conducted in Goba, prevalence of premarital sexual activities and associated factors among undergraduate health science students, Madda Walabu University (47\%.), Goba town.

A single population proportion formula of

$n=\left(\frac{Z \alpha}{2}\right)^{2} p \frac{(1-p)}{d^{2}}$

$\mathrm{P}=0.47$ (prevalence of premarital sexual activities)

$95 \%$ confidence interval

Margin of error $5 \%(d=0.05)$

Computing with the above formula and $10 \%$ of contingency for non-response rate gives a total sample size of 422 .

$$
n=\frac{(1.96)^{2} \times 0.47(1-0.47)}{0.05^{2}}=383
$$

$383 \times 10 / 100=39$ (non-response)

383 plus $39=422$

\section{Sampling procedure}

Robe TVET classes and respective numbers of students in the classes were identified and selected by using proportional allocation to sample size and simple random sampling technique was used to select study participants from each class (Figure 1).

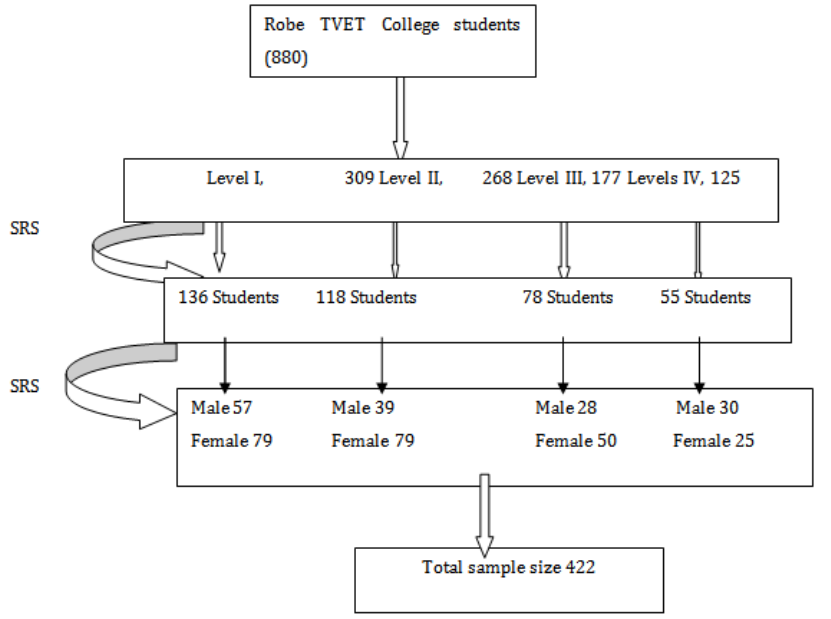

Figure I Schematic presentation of sampling procedure.

\section{Study variables}

\section{Independent variables}

Socio-demographic variables (age, sex, level, family size, parents' educational status and family monthly income).
Substance use (alcohol, Khat), cigarette smoking

\section{Dependent variables}

Premarital sexual practice

\section{Sample size determination and sampling procedure}

An institutional based cross sectional quantitative study design was used. The sample size for the quantitative study was determined using a single population proportion formula with the following assumption: Prevalence of pre-marital sex $47 \%,{ }^{18}$ margin of sampling error tolerated - 5\% (0.05), critical value at $95 \%$ confidence interval of certainty (1.96), 10\% for non-response making the final sample size of 422.Quantitative data were cleaned, edited \&entered in to epi info 3.2.1 and exported to the statistical packages for social science (SPSS) version 21 were used for further analysis .frequency distribution and cross tabulation were done against the variables of interest. Bi variate analysis was done to the association between explanatory variables and outcome variables of the study. Variables significant at p-value of 0.2 in vicariate analysis included in multi variable logistic regression model in which odds ratio with $95 \%$ confidence interval were estimated to identify independent predictors of premarital sexual practice. The structured questionnaire was adopted from literatures of similar study \&prepared by English language and translated to local language by an expertise of both languages and also retranslated back to English to check its consistency. Pilot study was conducted on 5\% of sample size Battu Terera TVET college of Goba town. Three trained data collectors of elementary school teachers and two supervisors were recruited. The data were collected by using self-administered questionnaire and then checked by supervisors on the field. Data were cleaned, coded and entered in to computer were done by data clerk. The supervisors checked each completed questionnaire and principal investigator monitored the overall quality of the data collection.

\section{Operational definitions}

A. Age of sexual debut: The age at which the first sexual intercourse occurred.

B. Monthly income: A total amount of money that earned monthly by somebody or by family members directly or indirectly.

C. Premarital sex: A penetrative vaginal sexual intercourse performed before formal marriage.

D. Substance abuse: pattern abuse of drug in which user consume the substance in amount or with methods which are harmful to themselves or others

E. Unprotected Sexual Activities: Sexual activities performed without protection from pregnancy and other STIs (without proper utilization of condom).

\section{Data management}

Data were analyzed by using SPSS Version 21. During the process of analyzing, frequency distributions, pie chart, figures and tables was used to present the data. Odd ratio was calculated on to determine the strength of association among variables.

\section{Ethical consideration}

Ethical clearance was obtained from the Ethical Committee of Madda Walabu University, Goba referral hospital. Letters of permission was obtained from Bale Zone Health Bureau and Goba Town Health Office. Informed consent was obtained from participants 
involved in the study. The participants were allowed to consider their participation and given the opportunity to withdraw from the study at any point in the course of the study if they wished to do so. Participants' name or personal identifier was not included in the written questionnaires to ensure participants' confidentiality.

\section{Dissemination of results}

Findings of the study will be communicated to the College where the study was conducted, to Ethiopian Ministry of Education to inform the importance of reproductive health for school adolescent, School of Health Science through soft and hard copy after presentation. The findings will also be disseminated to different organizations those have a contribution to promote health and prevent diseases related to adolescent reproductive health in the region and zone. The findings will also be presented in various seminars and workshops. The findings will finally be published to access to international journals as well.

\section{Results}

From a total of 422 study participants of 410 of them were responded with $97 \%$ response rate.

\section{Socio demographic characteristics}

The mean age of study participants were 21 years with standard deviation of 2.041 . One hundred eighty five $(47.8 \%)$ of the study subjects were males. About one third of study subjects $(35.1 \%)$ and $(30.5 \%)$, were level I and II respectively followed by level III (20.2\%) and level IV (14.2\%). Concerning the religion of study participants, 167(43.2\%) were Orthodox, 141(36.4) were Muslim, 61(15.8) Protestant and 18(4.7\%) other followers. Majority of the respondents ethnic group were Oromo, 291(75.2\%) followed by Amhara, 58(15.0\%), Tigre, 20(5.2\%) and others 18(4.6\%). Regarding their residential, 208(53.8) lives with their parents, 67(17.3\%) alone, $67(16 \%)$ with relatives, $45(11.6 \%)$ with friends. The mean of family size of study participants were 6.5 persons per household (Table 1) (Figure 2).

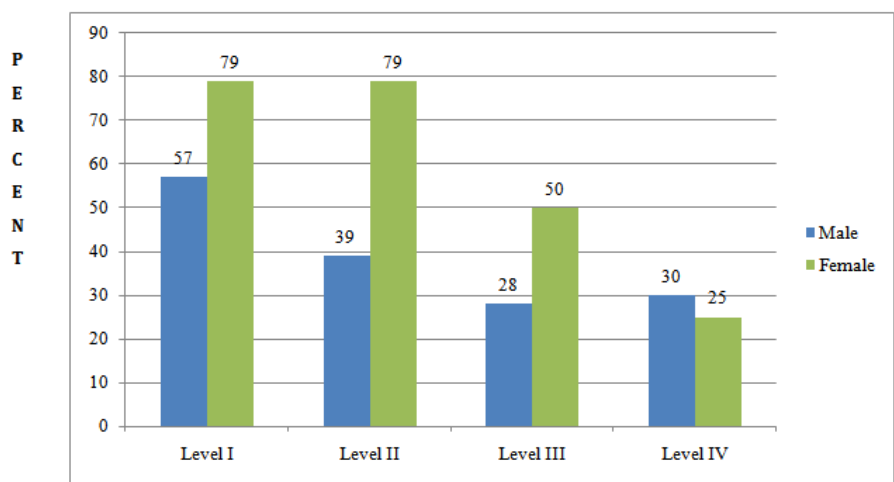

Figure 2 Level of education of Robe TVET College Students in June 2016 Level of education.

Regarding educational level of their fathers, 319(82.4\%) were literate, of which $250(64.6 \%)$ were formally educated and $69(17.8 \%)$ were informal education while $68(17.6 \%)$ were unable to read \& write. Their mothers' educational level was, 291(75.2\%) literate of which, 202(52.2\%) formal education, 89(23.0\%) informal education and the rest $96(24.8 \%)$ were unable to read \& write. The occupational status of their mothers were, $243(62.8 \%)$ housewife followed by merchants 69(17.8\%), employed 57(14.7\%) and $18(4.7 \%)$ were others. While the occupational status of their fathers were, 151(39.0\%) farmers, $128(33.1 \%)$ employed at governmental institution, 87(22.5\%) merchants, 21(5.4\%) unspecified. while 174 $(45.0 \%)$ of the respondents do not know their families monthly income while 53(13.7\%), of respondents family earned 4000 birr and above, followed by 57(14.7\%), earned 2501-4000 birr and the rest $103(26.6 \%)$ were earning <2500 birr per month (Table 2).

Table I Socio demographic characteristics of Robe TVET College Students, June, in 2016

\begin{tabular}{|c|c|c|c|}
\hline Variables & Categories & Frequency & Percentage \\
\hline \multirow{4}{*}{ Age } & 15-19years & 189 & 48.8 \\
\hline & 20- 25years & 196 & 50.6 \\
\hline & $>25$ years & 2 & 0.5 \\
\hline & Total & 387 & 100.0 \\
\hline \multirow{3}{*}{ Sex } & Male & 185 & 47.8 \\
\hline & Female & 202 & 52.2 \\
\hline & Total & 387 & 100.0 \\
\hline \multirow{5}{*}{ Religion } & Orthodox & 167 & 43.2 \\
\hline & Muslim & $14 \mid$ & 36.4 \\
\hline & Protestant & 61 & 15.8 \\
\hline & Others & 18 & 4.7 \\
\hline & Total & 387 & 100.0 \\
\hline \multirow{5}{*}{ Ethnic group } & Oromo & 291 & 75.2 \\
\hline & Amhara & 58 & 15 \\
\hline & Tigre & 20 & 5.2 \\
\hline & Others & 18 & 4.6 \\
\hline & Total & 387 & 100.0 \\
\hline \multirow{6}{*}{$\begin{array}{l}\text { Living } \\
\text { arrangement }\end{array}$} & $\begin{array}{l}\text { Live with } \\
\text { parents }\end{array}$ & 208 & 53.8 \\
\hline & $\begin{array}{l}\text { Live with } \\
\text { relative }\end{array}$ & 46 & 11.9 \\
\hline & $\begin{array}{l}\text { Live with } \\
\text { friend }\end{array}$ & 45 & 11.6 \\
\hline & Alone & 67 & 17.3 \\
\hline & $\begin{array}{l}\text { Live with } \\
\text { siblings }\end{array}$ & 21 & 5.5 \\
\hline & Total & 387 & 100.0 \\
\hline \multirow{4}{*}{ Family size } & $3-6$ & 217 & 56.1 \\
\hline & $7-11$ & 165 & 42.6 \\
\hline & $>11$ & 5 & 1.3 \\
\hline & Total & 387 & 100.0 \\
\hline
\end{tabular}

\section{Premarital sexual practice}

Regarding the premarital sexual practice, 201(51.9\%) of the respondents had sexual intercourse before marriage and the remaining, 186(48.1\%) had no premarital sexual practice. The mean 
age of premarital sexual practice was 17.7 years; with minimum age 14 and maximum age of 21years. About 28(13.9\%) of the respondents did not remember the age at which they started their first premarital sexual practice. Regarding the age of partners', they had first sexual intercourse at 17years with the minimum age of 12 and maximum of 25 years. They reported that, the major reason for engagement in premarital sexual practice, $118(58.7 \%)$ of the respondents reason related to personal desire or interest, followed by $49(24.4 \%)$ because of peer pressure, 23(11.4\%), due to influence of substance use (alcohol, chat and drug) and 11(5.5\%), were due to economic problems (Table 3 ) (Figure 3).

Table 2 Socio Demographic characteristics of Robe TVET College Students family in June, 2016

\begin{tabular}{|c|c|c|c|}
\hline Variables & Categories & Frequency & Percentage \\
\hline \multirow{4}{*}{$\begin{array}{l}\text { Fathers } \\
\text { educational status }\end{array}$} & literate & 250 & 64.6 \\
\hline & Read and write only & 69 & 17.8 \\
\hline & $\begin{array}{l}\text { Unable to read and } \\
\text { write (Illiterate) }\end{array}$ & 68 & 17.6 \\
\hline & Total & 387 & 100.0 \\
\hline \multirow{4}{*}{$\begin{array}{l}\text { Mothers } \\
\text { educational status }\end{array}$} & Literate & 202 & 52.2 \\
\hline & Read and write & 89 & 23.0 \\
\hline & Illiterate & 96 & 24.8 \\
\hline & Total & 387 & 100.0 \\
\hline \multirow{6}{*}{$\begin{array}{l}\text { Occupation of } \\
\text { mother }\end{array}$} & House wife & 243 & 62.8 \\
\hline & Employed & 57 & 14.7 \\
\hline & Merchant & 69 & 17.8 \\
\hline & Farmer & 5 & 1.3 \\
\hline & Others & 13 & 3.4 \\
\hline & Total & 387 & 100.0 \\
\hline \multirow{5}{*}{$\begin{array}{l}\text { Occupation of } \\
\text { father }\end{array}$} & Employed & 128 & 33.1 \\
\hline & Merchant & 87 & 22.5 \\
\hline & Farmer & 151 & 39.0 \\
\hline & Others & 21 & 5.4 \\
\hline & Total & 387 & 100.0 \\
\hline \multirow{6}{*}{$\begin{array}{l}\text { Family monthly } \\
\text { income }\end{array}$} & $\leq 15000$ ETB & 46 & 11.9 \\
\hline & $|50|-2500$ & 57 & 14.7 \\
\hline & 250I-4000 ETB & 57 & 14.7 \\
\hline & $\geq 4000$ ETB & 53 & 13.7 \\
\hline & Do not know & 174 & 45.0 \\
\hline & Total & 387 & 100.0 \\
\hline
\end{tabular}

\section{Contraceptive use}

Out of 201 respondents who had premarital sexual practice; $106(52.7 \%)$ of them reported history of contraceptive use at first premarital sexual practice, while the remaining 95(47.3\%) of them reported that they had their first sex without any contraceptive method. Among the respondents who used contraceptive method; 68(64.2\%) had used condom as method of contraceptive, followed by pills $27(25.5)$ and coitus withdrawal method reported by $11(10.4 \%)$ of the respondent. When we see the responses about the use of contraceptive method during their last sexual practice; $135(67.2 \%)$ of them reported the use of contraceptive method and while the remaining 66(32.8\%) of them not used any method at their last sexual practice. Condom was the main contraceptive method used by majority of the respondents, $91(67.4 \%)$ during the last sexual practice, followed by $20(14.8)$; rhythm, 18(13.2\%); pills, 6(4.4\%); withdrawal methods (Table 4).

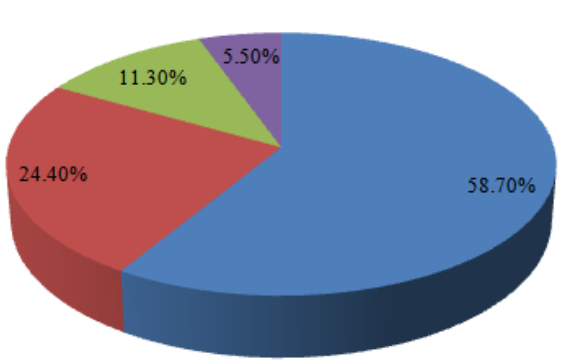

\section{key}

- personal desire

- peer pressure

influence of alcohol chat and drug

nother reasons

Figure 3 Reason for premarital sexual practice of Robe TVET College Students in June 2016.

Table 3 Premarital sexual practice of Robe TVET College Students, in June 2016

\begin{tabular}{llll}
\hline Variables & Categories & Frequency & Percentage \\
\hline \multirow{4}{*}{ Sexual feeling to opposite sex } & No & 254 & 65.6 \\
& Total & 133 & 34.4 \\
& $<16$ & 887 & 100.0 \\
Age of first sexual feeling to & $17-20$ & 122 & 34.3 \\
opposite sex & Do not know & 45 & 48.0 \\
& Total & 254 & 17.7 \\
\multirow{3}{*}{ Sexual intercourse } & Yes & 201 & 51.9 \\
& No & 186 & 48.1 \\
& Total & 387 & 100.0 \\
Age at first sexual intercourse & I7-20 & 133 & 66.2 \\
& Do not know & 28 & 13.9 \\
& Total & 201 & 100.0
\end{tabular}

\section{Unprotected sexual practice}

Majority of the respondents, 183(91.1\%) had sex with boy/girl friends as their first sexual partner followed by stranger, $12(6.0 \%)$. Regarding the status of the first sexual intercourse, 123(61.2\%) was wanted, 57(28.4\%) was unwanted, 15(7.5\%) was forced and 6(3.0\%) of respondents could not define it. Among study participants who experienced sexual intercourse, 201 largest proportion, 90(44.8\%) of them had sex with only one partner, $68(33.8 \%)$ had sex with two partners, $41(20.4 \%)$ of them had sex with three and more partners and the rest, $2(1.0 \%)$ do not remember the number of partners they had sex with. Concerning the individuals with whom they had sex with, $189(94.0 \%)$ of them had sex with their boy/girlfriends, $36(18.0 \%)$ of them had sex with a person whom they did not know, $18(9.0 \%)$ of them with individuals who had multiple sexual intercourse and $8(4.0 \%)$ of them had sex with a person who had sexual intercourse with commercial sex workers. Regarding condom utilization after unprotected sexual intercourse, out of 201 who had sexual intercourse, majority of them $160(79.6 \%)$ were using condom and $41(20.4 \%)$ 
were not using. Out of 160 of respondents who were using condom, $56(35.0 \%)$ were using always and sometimes and 48(30.0\%), were using most of the time. Out of 106 female students who had sexual intercourse, $19(17.0 \%)$ had experienced unwanted pregnancy and $87(82.1 \%)$, did not. Subsequently, $10(52.6 \%)$ of them delivered and $9(47.2 \%)$, of them aborted the pregnancy. Majority of the study participants, $249(63.3 \%)$ did not accept that premarital sexual practice is necessary and $138(35.7 \%$ ) of them accept it is necessary (Table 5) (Figure 4).

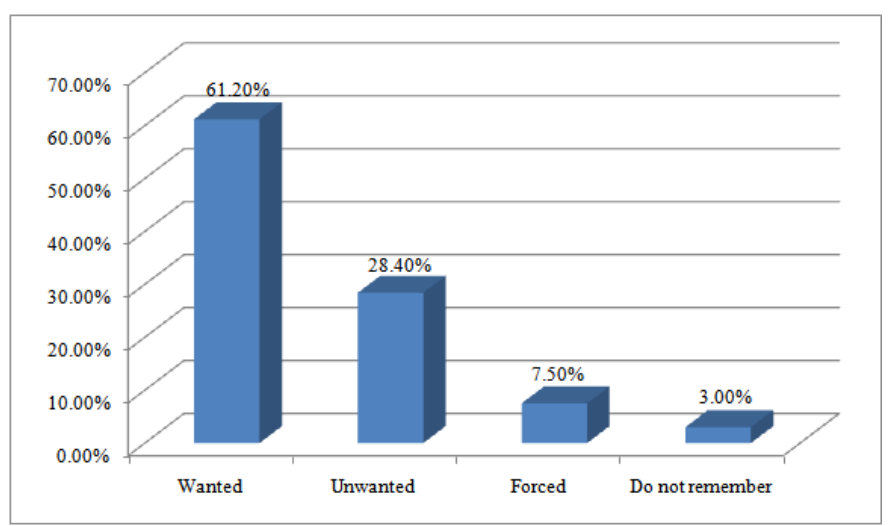

Figure 4 Status of first sex of Robe TVET Students, in June 2016.

Table 4 Contraceptive use of Robe TVET College Students, in June 2016

\begin{tabular}{|c|c|c|c|}
\hline Variables & Categories & Frequency & Percentage \\
\hline \multirow{3}{*}{$\begin{array}{l}\text { Use of contraceptive during } \\
\text { the first sexual intercourse }\end{array}$} & Yes & 106 & 52.7 \\
\hline & No & 95 & 47.3 \\
\hline & Total & 201 & 100.0 \\
\hline \multirow{4}{*}{$\begin{array}{l}\text { Method of contraceptives } \\
\text { used during the first sexual } \\
\text { intercourse }\end{array}$} & Condom & 68 & 64.2 \\
\hline & Pills & 27 & 25.5 \\
\hline & Withdraw & 11 & 10.4 \\
\hline & Total & 106 & 100.0 \\
\hline \multirow{3}{*}{$\begin{array}{l}\text { Use of contraceptive during } \\
\text { last sexual intercourse }\end{array}$} & Yes & 135 & 67.2 \\
\hline & No & 66 & 32.8 \\
\hline & Total & 201 & 100.0 \\
\hline \multirow{5}{*}{$\begin{array}{l}\text { Method of contraceptive } \\
\text { used during the last sexual } \\
\text { intercourse }\end{array}$} & Condom & 91 & 67.4 \\
\hline & Pills & 18 & 13.3 \\
\hline & Withdrawal & 6 & 4.4 \\
\hline & Rhythm & 20 & 14.8 \\
\hline & Total & 135 & 100.0 \\
\hline
\end{tabular}

\section{Sexual education}

Majority of the study participants, 364(94.1\%) accept that sex education was necessary and the rest $23(5.9 \%)$ did not. Majority of the study participants, $193(49.9 \%)$, were obtaining information of health education from Media and school, 154(39.8\%) and the rest from home, $97(25.1 \%)$, peers, $90(23.3 \%)$ and others from institutions, 114(29.5\%) (Table 6).

\section{Substance use}

Out of 387 study participants, majority of them (73.1\%), never drink alcohol (20.9\%), and drunk occasionally (2-3times/ month),
(3.6\%), drunk 2-3times per week and the rest, (2.3\%) drunk daily. From which most of them, $70(67.3 \%)$ were encouraged by their friends, $17(26.3 \%)$, start alcohol drinking by themselves, and the rest, $9(8.7 \%), 6(5.8 \%)$ and $2(1.9 \%)$, were encouraged alcohol drinking by their siblings, parents and the person whom they did not know respectively around the time they had unprotected sexual practice. The respondent's family, 115(29.7\%), were drinking alcohol, 263(68.8\%) were not and the rest, $9(2.3 \%)$, respondents did not know who drink alcohol in their family. Majority of the respondents $(89.0 \%)$ were not smoking and $(10 \%)$ of them were smoking cigarette. Out of 39 , majority of them $(56.4 \%)$ were encouraged by their friends which predispose them to had unprotected sexual practice. Regarding the prevalence of respondents' family smoking history ,(19.6\%) of them were smoking, of which, 39(51.1\%) were fathers, 15(19.9\%) siblings, $7(9.2 \%)$ mothers and the rest, $6(7.9 \%)$. Concerning chat chewing, $251(64.9 \%)$ were not chewing, and $136(35.1 \%)$ of them were chewing chat, from which majority of them, $70(51.1 \%)$ were influenced by peers pressure and the rests, 25(18.4\%), 20(14.7\%), 11(8.1\%), were encouraged chewing chat by their fathers, did not remember and by strangers respectively which subsequently cause them to practice unprotected sexual intercourse. When we see respondent's family behavior of chewing chat $144(37.2 \%)$, were chewing chat and $243(62.8 \%)$, of them were not chewing, from which majority of them, $39(51.3 \%)$ were fathers (Table 7$)$.

Table 5 Unprotected sexual activities of Robe TVET College Students, in 2016

\begin{tabular}{|c|c|c|c|}
\hline Variables & Categories & Frequency & Percentage \\
\hline \multirow{4}{*}{$\begin{array}{l}\text { Your first sexual } \\
\text { partner }\end{array}$} & Boy/girl friend & 183 & 91.0 \\
\hline & Stranger & 12 & 6.0 \\
\hline & Sex worker & 6 & 3.0 \\
\hline & Total & 201 & 100.0 \\
\hline \multirow{6}{*}{$\begin{array}{l}\text { Number of life } \\
\text { time's partners } \\
\text { had sex with }\end{array}$} & One & 90 & 44.8 \\
\hline & Two & 68 & 33.8 \\
\hline & $>$ two & 41 & 20.4 \\
\hline & Do not remember & 2 & 1.0 \\
\hline & Total & 201 & 100.0 \\
\hline & Boy/girl friend & 189 & 94.0 \\
\hline \multirow{3}{*}{$\begin{array}{l}\text { Individual had sex } \\
\text { with whom }\end{array}$} & $\begin{array}{l}\text { Person whom don't } \\
\text { know }\end{array}$ & 36 & 18.0 \\
\hline & $\begin{array}{l}\text { Person who had } \\
\text { multiple sexual } \\
\text { partner }\end{array}$ & 18 & 9.0 \\
\hline & $\begin{array}{l}\text { Person who had } \\
\text { sexual intercourse } \\
\text { with commercial } \\
\text { sex workers }\end{array}$ & 8 & 4.0 \\
\hline \multirow{4}{*}{$\begin{array}{l}\text { Condom } \\
\text { use during } \\
\text { unprotected } \\
\text { sexual activities }\end{array}$} & Yes & 160 & 79.6 \\
\hline & No & 41 & 20.4 \\
\hline & Total & 201 & 100.0 \\
\hline & Some times & 56 & 35.0 \\
\hline \multirow{3}{*}{$\begin{array}{l}\text { How often } \\
\text { condom used }\end{array}$} & Most of the time & 48 & 30.0 \\
\hline & Always & 56 & 35.0 \\
\hline & Total & 160 & 100.0 \\
\hline \multirow{3}{*}{$\begin{array}{l}\text { Experienced } \\
\text { Unwanted } \\
\text { pregnancy }\end{array}$} & Yes & 19 & 17.0 \\
\hline & No & 87 & 82.1 \\
\hline & Total & 106 & 100.0 \\
\hline
\end{tabular}


Table 6 Source of sex education of robe TVET College Students, in June 2016

\begin{tabular}{llll}
\hline Variables & & Frequency & Percentage \\
\hline \multirow{2}{*}{$\begin{array}{llll}\text { Sexual education is } \\
\text { necessity }\end{array}$} & Yes & 364 & 94.1 \\
& No & 23 & 5.9 \\
& Total & 387 & 100.0 \\
Preferred place of & Home & 129 & 75.2 \\
sexual education & Peers & 90 & 35.4 \\
needs to be given & Media & 187 & 24.7 \\
& Others & 96 & 51.4 \\
\hline
\end{tabular}

\section{Factors associated with premarital sexual practice}

The Logistic regression analysis showed that premarital sexual practice was more likely among Male TVET Students, $[\mathrm{AOR}=2.638$, 95\%CI $(1.731,3.950)]$, drinking Alcohol, $[\mathrm{AOR}=3.566,95 \% \mathrm{CI}$ (2.650, 4.773), chewing chat, $[\mathrm{AOR}=2.606,95 \% \mathrm{CI}(1.526,4.451)]$ and smoking cigarette, $[\mathrm{AOR}=6.451,95 \% \mathrm{CI}(3.332,12.501)]$. But it was found to be less likely among students whom their family's monthly income is $>4500$ ETB, [A0R $=0.268,95 \% \mathrm{CI}(0.137,0.524)$ ] and 3501-4500 ETB, [AOR 0.274, 95\% (0.143, 0.525)] (Table 8).

Table 7 Drug/Substance use of robe TVET College Students, in 2016

\begin{tabular}{|c|c|c|c|}
\hline Variables & Categories & Frequency & Percentage \\
\hline \multirow{5}{*}{ Alcohol consumption history } & Never drink & 283 & 73.1 \\
\hline & Occasionally(2-3times monthly) & 81 & 20.9 \\
\hline & 2-3times per a week & 14 & 3.6 \\
\hline & Drinks daily & 9 & 2.3 \\
\hline & Total & 387 & 100.0 \\
\hline \multirow{7}{*}{$\begin{array}{l}\text { Who encouraged you to drink } \\
\text { for the first time }\end{array}$} & Father & 3 & 2.9 \\
\hline & Mother & 3 & 2.9 \\
\hline & Siblings' & 9 & 8.7 \\
\hline & $\mathrm{k}_{\text {Peers }}$ & 70 & 67.3 \\
\hline & Stanger & 2 & 1.9 \\
\hline & None & 17 & 26.3 \\
\hline & Total & 104 & 100.0 \\
\hline \multirow{3}{*}{ Chewing chat } & Yes & 136 & 35.1 \\
\hline & No & 251 & 64.9 \\
\hline & Total & 387 & 100.0 \\
\hline \multirow{8}{*}{$\begin{array}{l}\text { Who encouraged you to chew } \\
\text { chat for the first time }\end{array}$} & Father & 25 & 18.4 \\
\hline & Mother & 3 & 2.2 \\
\hline & Siblings & 2 & 1.5 \\
\hline & ${ }_{v}$ Peers & 70 & 51.5 \\
\hline & Stranger & 11 & 8.1 \\
\hline & Do not remember & 20 & 14.7 \\
\hline & None & 5 & 3.6 \\
\hline & Total & 136 & 100.0 \\
\hline \multirow{5}{*}{ Frequency of smoking } & Smoke occasionally & 28 & 7.2 \\
\hline & Smoke 2-3 times weekly & 5 & 1.3 \\
\hline & Smoke daily & 6 & 1.6 \\
\hline & Never smoke & 348 & 89.9 \\
\hline & Total & 387 & 100.0 \\
\hline
\end{tabular}


Table Continued.

\begin{tabular}{|c|c|c|c|}
\hline Variables & Categories & Frequency & Percentage \\
\hline \multirow{5}{*}{$\begin{array}{l}\text { Who encouraged you to } \\
\text { smoke cigarette for the first } \\
\text { time }\end{array}$} & Father & 5 & 12.8 \\
\hline & Siblings & 6 & 15.4 \\
\hline & Peers & 22 & 56.4 \\
\hline & Do not remember & 6 & 15.4 \\
\hline & Total & 39 & 100.0 \\
\hline \multirow{4}{*}{ Smoke cigarette in family } & Yes & 76 & 19.6 \\
\hline & No & 301 & 77.8 \\
\hline & I do not know & 10 & 2.6 \\
\hline & Total & 387 & 100.0 \\
\hline \multirow{5}{*}{ Who smokes in your family } & Father & 39 & 51.3 \\
\hline & Mother & 7 & 9.2 \\
\hline & Both father and mother & 6 & 7.9 \\
\hline & Brother and sister & 15 & 19.9 \\
\hline & Stranger & 15 & 19.9 \\
\hline \multirow{3}{*}{ Does your family chew chat } & Yes & 144 & 37.2 \\
\hline & No & 243 & 62.8 \\
\hline & Total & 387 & 100.0 \\
\hline \multirow{5}{*}{ Who chew chat in your family } & Father & 95 & 66.0 \\
\hline & Mother & 14 & 9.7 \\
\hline & & & \\
\hline & Both father and mother & 17 & 11.8 \\
\hline & Brothers and sisters & 58 & 40.3 \\
\hline \multirow{4}{*}{ Do your family drink } & Yes & 115 & 29.7 \\
\hline & No & 263 & 68.0 \\
\hline & I do not know & 9 & 2.3 \\
\hline & Total & 387 & 100.0 \\
\hline \multirow{4}{*}{$\begin{array}{l}\text { Who drink alcohol in the } \\
\text { family }\end{array}$} & Father & 69 & 60.0 \\
\hline & Mother & 3 & 2.6 \\
\hline & Both father and mother & 16 & 13.9 \\
\hline & Brother and sister & 49 & 42.6 \\
\hline
\end{tabular}

Table 8 factors associated with premarital sexual practice among Robe TVET College, June 2016

\begin{tabular}{llllll}
\hline Variables & Categories & Crude OR $(\mathbf{9 5} \% \mathbf{C l})$ & P-value & Adjusted OR(95\% Cl) & P value \\
\hline Sex & Female & $\mathrm{R}$ & & $\mathrm{R}$ & \\
& Male & $0.662(0.443,0.989)$ & 0.044 & $2.63(1.75,3.95)$ & 0.008 \\
$\begin{array}{l}\text { Parents } \\
\text { Monthly } \\
\text { income }\end{array}$ & < $500 \mathrm{ETB}$ & $\mathrm{R}$ & & $\mathrm{R}$ & \\
& $350 \mathrm{I}-4500 \mathrm{ETB}$ & $0.250(0.044,1.43)$ & 0.019 & $0.274(0.143,0.525)$ & 0.000 \\
\hline
\end{tabular}


Table Continued.

\begin{tabular}{llllll}
\hline Variables & Categories & Crude OR (95\% Cl) & P-value & Adjusted OR(95\%Cl) & P value \\
\hline Drink & No & $\mathrm{R}$ & & $\mathrm{R}$ & \\
Alcohol & Yes & $2.43(1.04-5.65)$ & $0.002 \mathrm{I}$ & $3.56(2.65,4.77)$ & 0.039 \\
\multirow{2}{*}{ Chewing chat } & No & $\mathrm{R}$ & & $\mathrm{R}$ & \\
& Yes & $0.447(0.290,0.687)$ & 0.000 & $2.606(1.526,4.45 \mathrm{I})$ & 0.000 \\
\multirow{2}{*}{ Smoking cigarette } & No & $\mathrm{R}$ & & $\mathrm{R}$ & \\
& Yes & $4.49(2.67-7.55)$ & 0.000 & $6.45(3.33-12.50)$ & 0.000 \\
\hline
\end{tabular}

*R, reference;Values typed in bold=significant

\section{Discussion}

The prevalence of premarital sexual practice among study participant was $51.9 \%$ with mean age of 17.7 years and maximum age 21 and minimum ages 14 . When compared to study conducted at Nekemte, premarital sex was $21.4 \%{ }^{19}$ and Agaro High school, $25 \% .{ }^{20}$ The premarital sexual practice is higher when compared to these studies because participants of this study are affected by peer pressure and living separated from their parents where family fear and control is not available. ${ }^{19,21,22}$ Being adolescent and early adulthood is characterized by different types of risky behaviors, including risky sexual practice, substance abuse and exposure to STIs. ${ }^{23}$ Adolescents and college students premarital sex is increasing around the world many of which are risky, unplanned and unprotected. ${ }^{18,24,25}$ The mean age of first sexual intercourse of the study participants at which 17.7years which is higher than the study conducted at Addis Ababa was 12 years for boys and 14years for girls. ${ }^{26}$ This is may be due to many of the study participants are from rural area living in the town for education. The main reason of having sexual intercourse of study subjects is personal desire, $118(58.7 \%)$ followed by peer pressure, 49(24.4), substance use, 23(11.4\%). But the reason of having premarital sex among Addis Ababa high school students was peer pressure $(35.2 \%)$ rape and use of drugs which is comparable to the current study (38). Out of study participants who experience premarital sex $90(44.8 \%)$ had only one sexual partners whereas $68(33.8 \%)$ had two sexual partners and the remaining, 43(21.4\%) of them had more than two sexual partners. Similarly the study conducted among Agaro High school students showed that 55.6\% had one sexual partner. ${ }^{19}$ Using condom during sexual intercourses is one of the preventive methods of STIs including HIV/AIDS and unwanted pregnancy. $52.7 \%$ of study participants were used condom during first sexual intercourse and 67.25 were used condom during their most recent sexual intercourse. When compared to the study conducted in different parts of Ethiopia, among secondary school students, in North West Ethiopia, $45.9 \%$ were used condom ${ }^{27}$ and among Agaro High school students, $54.4 \%$ were used condom during their sexual practice. ${ }^{19}$ The study subjects of this study area were highly utilized condom during their sexual practice the reason behind may be due to level of education and better access to reproductive health. Out of total respondents $26.8 \%$ drinking alcohol, $10.0 \%$ of them smoking cigarette and $35.1 \%$ were chewing chat. Study conducted to other part of Ethiopia, West Shoa, showed that, $16.7 \%$ of respondents reported to chewing chat and $66.7 \%$ of them were consuming alcohol. When we compare alcohol consumption, it is lower than in this study, this may because of low income and religion implications. ${ }^{28-36}$ But smoking cigarette and chewing chat are comparable. Sex and respondent's family's monthly income were among socio demographic variables associated with premarital sexual practice. Male students are 2.638 at risk to experience premarital sexual practice compared to female students. But it was found to be less likely among students whom their family's monthly income is $>4500$ ETB and 3501-4500 ETB compared to whom respondents monthly family income is $<1500$. This may be because of respondents whom family incomes is less is more likely to be involved in premarital sexual practice for economic problem than whom family's monthly income is more. It was found that respondents who drink alcohol were $3.56(2.65,4.77)$ at risk to practice premarital sex than who never drink alcohol, who chew the chat were $2.60(1.52,4.45)$ at risk to practice premarital sex than who did not chew and who smoke cigarette were $6.45(3.33,12.50)$ at risk to practice premarital sex. ${ }^{37-46}$ When we compare with study conducted at West Shoa Zone, Oromia regional state, students who drink alcohol were 2.6times more likely to be involved in premarital sexual practice when compared to students who did not drink alcohol.

\section{Conclusion}

The study revealed that the prevalence of premarital sex among the study participants is higher. Male sex, respondents' family monthly income, alcohol consumption, smoking cigarette and chewing chat are factors associated with premarital sexual practice. Colleges should work with health institutions to set reproductive health and to reduce premarital sexual practice and its risk.

\section{Recommendation}

Zonal health department and educational offices at different level should work together in order of promoting open discussion about sexual related issues and provide adequate and updated reproductive related information through school health education, by establishing reproductive health club in the college. Awareness creation should be done among TVET students to avoid unhealthy behaviors like substance use (drinking alcohol), watching videos that push them to start pre-marital sexual practice. Finally Robe town administration should design persistent and effective health education to decrease pre-marital sexual debut in unmarried adolescent students.

\section{Acknowledgements}

Our special gratitude and appreciation goes to Madda Walabu University, Goba referral hospital, Department of Public Health for giving us the opportunity to conduct research from which we learn many things.

\section{Conflict of interest}

Author declares that there is no conflict of interest.

\section{References}

1. Special Program of Research Development and Research Training in Human Reproductive Health (HRP). Progress in Reproductive Health Research. UNDO/UNFP/WHO; 2003. 
2. Special program of research development and research training in human reproductive health. World Bank. UNDO, UNFPA, WHO; $2005 ; 64: 241-312$.

3. Sujay R. Premarital sexual behavior among unmarried college students. Health and Population Innovation Fellowship Program. 2005;10:15.

4. The State of World Population, UNFAP. Geneva; 2006.

5. Rweng M. Sexual risky behavior among Young People in Bamenda, Cameroon. International Family Planning Perspectives. 2000;26:118-121.

6. Bearman PS, Bruckner H. Peer Effects on Adolescent Girls' Sexual Debut and Pregnancy risk. National Campaign to Prevent Teen Pregnancy. 1999.

7. Marin BV, Kirby DB, Hudes ES, et al. Boyfriends, girlfriends and teenagers' risk of sexual involvement. Perspectives on Sexual and Reproductive Health. 2006;38:76-83.

8. Bongaarts J, Cohen B. Adolescent reproductive behavior in the developing world Introduction and overview. Stud Fam Plann. 1998;29(2):99-105.

9. Lamptey PR. Reducing heterosexual transmission of HIV in poor countries. BMJ. 2002;324(7331):207-211.

10. Michelo C, Sandoy IF, Dzekedzeke K, et al. Steep HIV prevalence declines among young people in selected Zambian communities population-based observations (1995-2003). BMC Public Health. 2006;6:279.

11. Grao G. Gender, Sexuality, and HIV/AIDS: The What, the Why, and the How Plenary address on the XII the International AIDS Conference. Washington, USA; 2000.

12. Reminick AR. The Symbolic Significance of Ceremonial Defloration among the Amhara of Ethiopia. American Ethnologist. 1976;3(4):751-763

13. Fekadu Z. Casual sex debuts among female adolescents in Addis Ababa. Ethiop J Health Dev. 2001;15(2):109-116.

14. Fikadu, Fikadu K. Creating a better future for Ethiopian Youth A conference on ARH. The David and Lucile Packard Foundation Bahir Dar. Ethiopia; 2002;6(9):2000.

15. Correlates of unwanted pregnancy in Ethiopia. 2013.

16. Yi S, Poudel KC, Yasuoka J, et al. Role of risk and protective factors in risky sexual behavior among high school students in Cambodia. $B M C$ Publ Health. 2010;10:477.

17. Eaton DK, Kann L, Kinchen S, et al. Youth risk behavior surveillanceUnited States, 2005. MMWR Sur veil Summ. 2006;55(5):1-108.

18. Hubert M, Bajos N, Sandfort T. Sexual behaviour and HIV/AIDS in Europe: Comparisons of national surveys. London: UCL Press; 1998.

19. Kebede D, Alem A, Mitike G, et al. Khat and alcohol use and risky sex behaviour among in-school and out-of-school youth in Ethiopia. BMC Public Health. 2005;5:109.

20. O’Donnell L, O'Donnell CR, Stueve A. Early sexual initiation and subsequent sex related risks among urban minority youth: the reach for health study. Fam Plann Perspect. 2001;33(6):268-275.

21. Girma B, Assefa D, Tushunie K. Determinants of condom use among Agaro high school students using behavioral models. Ethiopian J Health Dev. 2004;18(1):25-30.

22. Kalix P. Khat scientific knowledge and policy issues. $\mathrm{Br} J$ Addict. 1987;82(1):47-53.

23. Sarah B. Shireen jejeebhy, Iqubal shah, et al. Towards adulthood. Exploring the Sexual and Reproductive Health of adolescents in South Asia. USA: WHO Geneva; 2003.
24. Adhikari R, Tamang J. Premarital sexual behavior among male college students of Kathmandu, Nepal. BMC Pub Health. 2009;9:241.

25. McManus A, Dhar L. Study of knowledge, perception and attitude of adolescent girls towards STIs/HIV, safer sex and sex education: (a cross sectional survey of urban adolescent school girls in South Delhi, India). BMC Women's Health. 2008;8:12.

26. Adolescent Reproductive Health. Global and national initiatives and lessons learned EPHAARH Task force. Ethiopian Public Health Association (EPHA), Addis Ababa, Ethiopia; 2003.

27. Dessalegn W. An Assessment of premarital sexual practice and Factors Contributing to premarital sex among High School Adolescents In Nekemte Town, E/Wollega zone, Oromia regional state. 2006.

28. Family planning method and practice. 2nd ed. Center for Disease Control and Prevention. Adolescent women and Reproductive Health, Africa, Atlanta; 1999.

29. Wight D, Plummer ML, Mshana G, et al. Contradictory sexual norms and expectations for young people in rural Northern Tanzania. Soc Sci Med. 2006;62(4):987-997.

30. Adolescent Health and Development in Nepal, Status, Issues, Programs and Challenges- Country Profile 2005. Department of Health Services, Family Health Division and CREHPA, Ministry of Health and Population, Nepal; 2005.

31. Brener N, Kann L, Lowry R, et al. Trends in HIV-related risk behaviors among high school students-United States, 1991-2005. Morbidity and Mortality Weekly Report. 2006;55(31):851-854.

32. Ross J, Godeau E, Dias S, et al. Young people's health in context. Health Behaviour in School-aged Children (HBSC) study: International report from the 2001/2002 survey. Geneva: World Health Organization; 2004. p. $153-160$.

33. Tamang A, Nepal B, Puri M, et al. Sexual Behaviour and Risk Perception among Young Men Engaged Border towns of Nepal. Asia Pacific Population Journal. 2001;16(2):195-210.

34. Survey of Teenagers in Seven Districts of Nepal, UNAIDS and UNICEF, Kathmandu, Nepal; 2001.

35. Mensch Barbara S, Grant MonicaJ, Blanc Ann K. The changing context of sexual initiation in sub-Saharan Africa. Population and Development Review. 2006;32(4):699-727.

36. Hattori Megan Klein, Larsen Ulla. Motherhood status and union formation in Moshi, Tanzania 2002-2003. Population Studies. 2007;61(2):185-199.

37. Grant Monica, Hallman Kelly. Pregnancy-related school dropout and prior school performance in KwaZulu-Natal, South Africa. Stud Fam Plann. 2008;39(4):369-382.

38. Lucy MI, Boukary O. High risk sexual behavior: Knowledge, attitudes and practice among youths at Kichangani ward, Tanga, Tanzania; 2004

39. Nancy Luke, Hong wei $\mathrm{Xu}$, Blessing U, et al. Migration Experience and Premarital Sexual Initiation in Urban Kenya: An Event History Analysis. Stud Fam Plann. 2012;43(2):115-126.

40. Weiss L, Whelan Band Gupta A. Adolescents and HIV/AIDS in developing world. International center for research on women. 1996.

41. Mitike G, Lemma W, Berhane F, et al. HIV/AIDS Behavioral Surveillance Survey Ethiopia. Round one. 2002.

42. Eshetu F, Zakus D, Kebede D. The attitude of students, parents and teachers towards the promotion and provision of condoms for adolescents in Addis Ababa. Ethiopian J Health Dev. 1997;11(1):7-11.

43. Ismail S, Bitsuamlak H, Alemu K. High risk sexual behaviors for STD/ HIV, pregnancies and contraception among high school students in rural town, northwest Ethiopia. Ethiopian J Health Dev. 1997;11(1):29-36. 
44. Netsanet F, Abebe M. Risky Sexual Behaviors And Associated Factor Among Male and Female Students. In Jimma Zone Preparatory Schools, South West Ethiopia. Ethiop J Health Sci. 2014;24(1):59-68.

45. Argyro C, Christopher H, Vlad islav RM, et al. Psychosocial predictors of sexual initiation and high-risk sexual behaviors in early adolescence. Child Adolescent Psychiatry Mental Health. 2007;1(1):14.
46. Getabalew Endazenaw, Mitsiwat Abebe. Assessment of Premarital Sexual Practices and determinant Factors among high school students in West Shoa Zone. Oromia Regional State, Ethiopia; 2015. 